\title{
Rhabdochona mexicana sp. n. (Nematoda: Rhabdochonidae) from the intestine of characid fishes in Mexico
}

\author{
Juan Manuel Caspeta-Mandujano ${ }^{1,2},{\text { František } \text { Moravec }^{1} \text { and Guillermo Salgado-Maldonado }}^{3}$ \\ ${ }^{1}$ Institute of Parasitology, Academy of Sciences of the Czech Republic, Branišovská 31, 37005 České Budějovice, Czech \\ Republic; \\ ${ }^{2}$ Centre for Biological Research, Autonomous University of Morelos State, Av. Universidad No. 1001, Col. Chamilpa, \\ C.P. 62210, Cuernavaca, Morelos, Mexico; \\ ${ }^{3}$ Institute of Biology, National Autonomous University of Mexico, A.P. 70-153, 04510 México, D.F., Mexico
}

Key words: Nematoda, Rhabdochona, Astyanax, freshwater fish, Mexico

\begin{abstract}
A new nematode, Rhabdochona mexicana sp. n., is described based on specimens recovered from the intestine of two species of fishes, Astyanax mexicanus (De Filippi) (type host) and Astyanax fasciatus (Cuvier) (Characidae: Characiformes) in central Mexico. This species is characterised by the following characters: 10 anteriorly directed teeth in the prostom, a larger (left) spicule which is slender in form with a small bifurcation at its distal tip covered by a cuticular membrane, a smaller (right) spicule without a barb at its distal tip, eggs bearing an irregular flock-like coating, and a conical tail without a cuticular spike (in both sexes).
\end{abstract}

In America, 19 Rhabdochona Railliet, 1916 species have so far been reported from the intestine of freshwater fishes (16 in North America, 1 in West Indies and 2 in South America). Three species and subspecies of Rhabdochona have so far been reported from fresh waters in Mexico: Rhabdochona kidderi kidderi Pearse, 1936 from Rhamdia guatemalensis (Günther), Ogilbia pearsei (Hubbs), and Gambusia yucatana Regan in cenotes (=sinkholes), cave waters and other water bodies in Yucatán; R. kidderi texensis Moravec et Huffman, 1988 from Cichlasoma fenestratum (Günther) and C. urophthalmus (Günther) from Yucatán and from Catemaco Lake, Veracruz; $R$. lichtenfelsi SánchezAlvarez, García-Prieto et Pérez-Ponce de León, 1998 from Goodea atripinnis Jordan, Alloophorus robustus (Bean) and Neoophorus diazi (Meek) in Pátzcuaro and Cuitzeo Lakes (Moravec 1998).

Recent investigations into helminth parasites of freshwater fishes, carried out by the research teams of the Institute of Biology, National Autonomous University of Mexico (UNAM) and the Centre for Biological Research, Autonomous University of Morelos State, in several river drainage systems in central Mexico, revealed the presence of a new species of Rhabdochona, which is described below.

\section{MATERIALS AND METHODS}

The nematodes studied were recovered from the intestine of Astyanax mexicanus (De Filippi) from four localities (Estorax, El Oasis, Fracción de Sánchez and El Rascón) in the Panuco River drainage system in central Mexico, collected from May to November 1996 and that of Astyanax fasciatus
(Cuvier) from four localities (Cuyotepeji, Petlalcingo, San Agustín Atenango and Petatlán) in the Balsas River drainage system in central Mexico, collected from July to October 1998.

The nematodes were fixed in hot $4 \%$ formaldehyde and cleared with glycerine for examination. Drawings were made with the aid of an Aristoplan microscope drawing attachment. After examination, the specimens were stored in $70 \%$ ethanol. All measurements are given in millimetres unless otherwise stated. Type specimens have been deposited in the National Helminthological Collection of the Institute of Biology, National Autonomous University of Mexico (UNAM) in Mexico City and in the Helminthological Collection of the Institute of Parasitology, Academy of Sciences of the Czech Republic (ASCR), in České Budějovice.

\section{RESULTS}

Rhabdochona mexicana sp. $\mathrm{n}$.

Figs. 1, 2

Description: Medium sized nematodes with smooth cuticle. Oval mouth opening surrounded by four minute cephalic papillae and two lateral amphids. Prostom funnel-shaped, wide, with basal teeth, anterior margin of prostom armed internally with 10 teeth (exceptionally 11) (3 dorsal, 3 ventral and 2 lateral on each side) (Fig. 2A-C). Vestibule relatively long. Small deirids bifurcate (Fig. 2 D), situated short distance posterior to prostom. Tail of both sexes conical, with rounded end, without terminal spike (Fig. 2 E).

Male (based on 20 specimens from $A$. mexicanus and 3 specimens from $A$. fasciatus; measurements of holotype in parentheses): Length of body 4.55-9.23 (8.71), maximum width 0.079-0.188 (0.151). Prostom

Address for correspondence: J.M. Caspeta-Mandujano, Institute of Parasitology, Academy of Sciences of the Czech Republic, Branišovská 31, 37005 České Budějovice, Czech Republic. Phone: ++ 42038777 5410; Fax: 420385300388 ; E-mail: juan@paru.cas.cz 

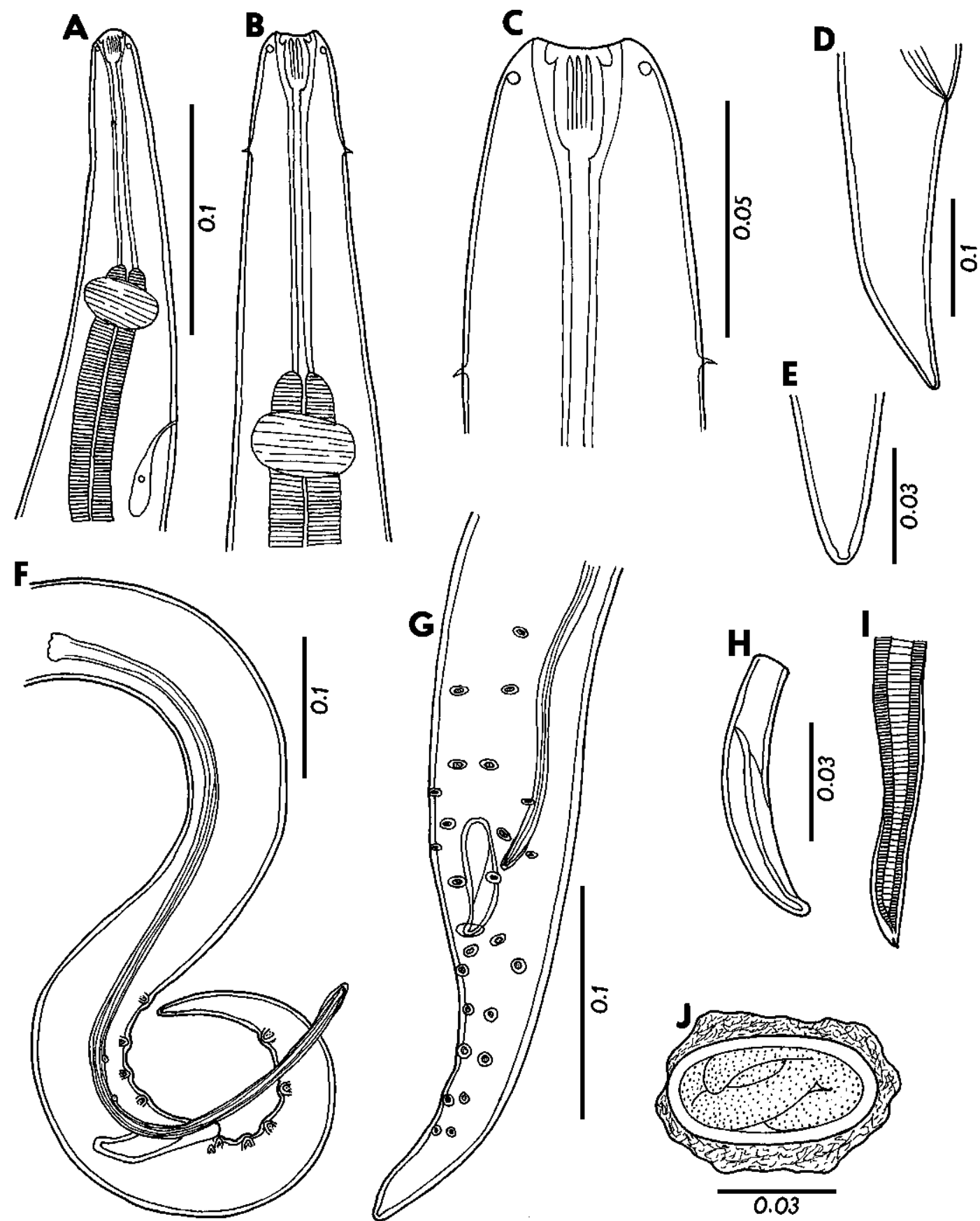

Fig. 1. Rhabdochona mexicana sp. n. A - anterior end of male, lateral view; B - anterior end of female, ventral view; $\mathbf{C}-$ cephalic end of female, ventral view; D - female tail; $\mathbf{E}$ - tail tip of male; F, G - posterior end of male, lateral and ventral views; $\mathbf{H}$ - right spicule; I - distal end of left spicule; $\mathbf{J}$ - egg. Scale bars in $\mathrm{mm}$. 


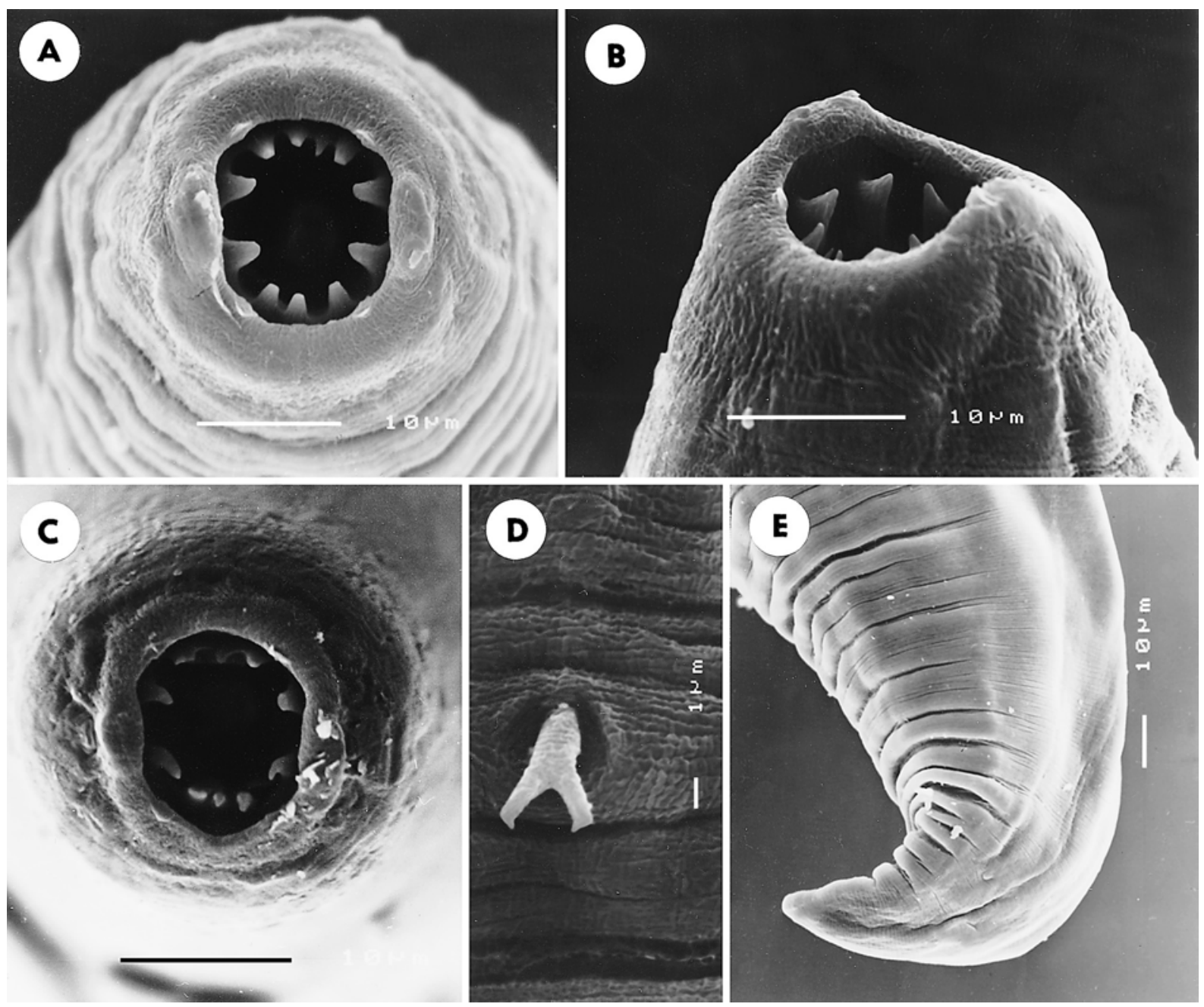

Fig. 2. Rhabdochona mexicana sp. n., SEM micrographs. A - cephalic end, apical view (specimen from Astyanax fasciatus with atypical number of teeth); B - anterior end, ventrolateral view; $\mathbf{C}$ - cephalic end, apical view (specimen from Astyanax mexicanus); $\mathbf{D}$ - deirid; $\mathbf{E}$ - female tail. Scale bar: $\mathbf{C}=10 \mu \mathrm{m}$.

0.019-0.026 (0.023) long and 0.013-0.023 (0.019) wide. Length of vestibule including prostom $0.115-0.161$ (0.151), of muscular oesophagus $0.184-0.280$ (0.277), of glandular oesophagus 1.50-4.55 (2.93). Nerve ring, excretory pore and deirids $0.135-0.188(0.171), 0.204-$ 0.306 (0.264) and 0.039-0.059 (0.046), respectively, from anterior extremity. Subventral preanal papillae: 3 or 4 papillae on one side and 5 papillae on the other side. Additional two pairs of lateral preanal papillae present between first, second and third subventral preanal pairs (counting from cloacal opening). Postanal papillae: six pairs; second pair lateral, remaining pairs subventral. Area rugosa absent. Larger (left) spicule $0.468-0.587$ (0.534) long, length of its shaft 0.138 $0.178(0.158)$ (representing 26-37\% (32\%) of whole spicule length); distal tip reduced, ending in a small bifurcation covered by narrow membrane. Smaller (right) spicule 0.082-0.108 (0.102) long, without dorsal barb. Length ratio of spicules 1 : 5.2-6.9 (5.2). Tail conical, 0.165-0.217 (0.217) long.

Female (based on 20 specimens from $A$. mexicanus and 5 specimens from $A$. fasciatus; measurements of allotype in parentheses): Length of body of gravid specimens 8.90-18.18 (17.17), maximum width 0.155$0.300(0.290)$. Prostom $0.023-0.033(0.033)$ long and 0.019-0.026 (0.019) wide. Length of vestibule including prostom $0.102-0.234$ (0.184), of muscular oesophagus 0.214-0.425 (0.356), of glandular oesophagus 2.40-5.41 (4.38). Nerve ring, excretory pore and deirids 0.165 0.250 (0.204), 0.250-0.359 (0.300), and 0.052-0.075 (0.075), respectively, from anterior extremity. Tail conical, 0.101-0.224 long. Vulva postequatorial, 4.9610.89 (9.99) from anterior end of body. Muscular vagina directed posteriorly. Uterus not reaching level of posterior end of oesophagus anteriorly. Size of mature (larvated) eggs $0.036-0.039 \times 0.019 \mathrm{~mm}$; surface of eggs with fine, irregular flock-like coating. 
T y p e h o s t: Astyanax mexicanus (De Filippi) (Characidae: Characiformes).

$\mathrm{O}$ t h e r h o s t: Astyanax fasciatus (Cuvier).

$\mathrm{S}$ i t e of in fection: Intestine.

$\mathrm{T}$ y p e 1 o c a 1 i t y : River near the village of Estorax $\left(21^{\circ} 02^{\prime} 28^{\prime \prime} \mathrm{N}, 99^{\circ} 46^{\prime} 57^{\prime \prime} \mathrm{W}\right)$, Mexico.

O t h e r 1 o c a 1 i t i e s : El Oasis Brook $\left(21^{\circ} 00^{\prime} 02^{\prime \prime} \mathrm{N}\right.$, $99^{\circ} 42^{\prime} 43$ 'W), brook near the village of Fracción Sánchez $\left(21^{\circ} 40^{\prime} 05^{\prime} \mathrm{N}, 100^{\circ} 41^{\prime} 11^{\prime \prime} \mathrm{W}\right)$ and El Rascón River $\left(22^{\circ} 00^{\prime} 04^{\prime \prime} \mathrm{N}, 99^{\circ} 15^{\prime} 01^{\prime \prime} \mathrm{W}\right)$ in the Panuco drainage system; brook near the village of Cuyotepeji $\left(17^{\circ} 57^{\prime} 35^{\prime \prime} \mathrm{N}\right.$, $\left.97^{\circ} 41^{\prime} 06^{\prime \prime} \mathrm{W}\right)$, brook near the village of Petlalcingo $\left(18^{\circ} 04^{\prime} 35^{\prime \prime} \mathrm{N}, 97^{\circ} 55^{\prime} 29^{\prime \prime} \mathrm{W}\right)$, brook near the village of San

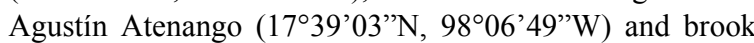
near the village of Petatlán $\left(17^{\circ} 35^{\prime} 31^{\prime \prime} \mathrm{N}, 99^{\circ} 00^{\prime} 27^{\prime \prime} \mathrm{W}\right)$ in the Balsas drainage system; Mexico.

$\mathrm{Prevale} \mathrm{nce}$ and in te n s it y: A. mexicanus: River near the village of Estorax: 59\% (32 fishes infected / 54 fishes examined), 1-6 (mean 2) nematodes per infected fish in May; El Oasis Brook: 58\% (7 / 12), 1-7 (mean 3) in May and $67 \%(25 / 37), 1-12$ (mean 2$)$ in November; brook near the village of Fracción de Sánchez: 22\% (11 / 49), 1-8 (mean 3) in October; El Rascón River: 5\% (1/21), 1 in November. A. fasciatus: brook near the village of Cuyotepeji: $18 \%$ (2/11), 1-2 (mean 1.5); brook near the village of Petlalcingo: $(1 / 9), 1$; brook near the village of San Agustín Atenango: 53\% (8/15), 1-2 (mean 1.5); brook near the village of Petatlán: $50 \%(1 / 2), 1$.

De p o s ition of s p e c i m e n s: Holotype, allotype and paratypes in the Institute of Biology, UNAM, in Mexico City (Cat. Nos. 3886, 3887, 3888) and paratypes in the Institute of Parasitology, ASCR, in České Budějovice (Cat. No. N-758)

E t y m o log $\mathrm{y}$ : The specific name is derived from the name of the country of origin.

\section{DISCUSSION}

Nematodes of the genus Rhabdochona are widely distributed intestinal parasites of freshwater fishes (Moravec and Coy Otero 1987, Moravec 1994). According to Sánchez-Alvarez et al. (1998), 97 nominal species have so far been described. Twenty one species and subspecies have been reported from America: Rhabdochona acuminata (Molin, 1860), R. californiensis Maggenti, Abdel-Rahman et Del Prado, 1992, $R$. canadensis canadensis Moravec et Arai, 1971, R. canadensis bifilamentosa Moravec et Huffman, 1988, $R$. cascadilla Wigdor, 1918, R. catostomi Kayton, Kritsky et Tobias, 1979, $R$. cotti Gustafson, 1949, $R$. cubensis Moravec et Coy Otero, 1987, R. decaturensis Gustafson, 1949, R. kidderi kidderi Pearse, 1936, R. kidderi texensis Moravec et Huffman, 1988, R. kisutchi Margolis, Moravec et McDonald, 1975, R. lichtenfelsi Sánchez-Alvarez, García-Prieto et Pérez-Ponce de León, 1998, $R$. longleyi Moravec et Huffman, 1988, $R$. milleri Choquette, 1951, R. ovifilamenta Weller, 1938, R. paxmani Maggenti, Abdel-Rahman et Del Prado,
1992, R. rotundicaudatum Byrne, 1992, R. salmonis Maggenti, Abdel-Rahman et Del Prado, 1992, $R$. uruyeni Díaz-Ungría, 1968, and $R$. zacconis Yamaguti, 1936. Most of them were reported from North America. Rhabdochona zacconis was only listed by Arai and Mudry (1983) and there is no description of this species from North America.

Rhabdochona mexicana belongs to a group of species possessing 10 anterior teeth in the prostom. In America this group includes: $R$. kisutchi described from Pacific salmon, Oncorhynchus kisutch (Walbaum), from British Columbia, Canada; R. catostomi from suckers, Catostomus catostomus (Foster) and C. ardens Jordan et Gilbert, from Alberta, Canada; $R$. paxmani and $R$. salmonis from rainbow trout, Oncorhynchus mykiss (Walbaum), from California, USA; R. lichtenfelsi from goodeids, Alloophorus robustus, Goodea atripinnis and Neoophorus diazi from Michoacán, Mexico. The rest of the species possess 6,14 or 16 teeth in the prostom. Rhabdochona mexicana differs from the other species possessing 10 teeth in having no dorsal or ventral barb on the spicules. This is except for R. lichtenfelsi, which can easily be distinguished by its filamented mature eggs; moreover, both species distinctly differ in the shape of the distal end of the left spicule, in addition to some other features.

Moreover, Rhabdochona mexicana markedly differs from $R$. kisutchi in the character of eggs (eggs with irregular flock-like coating vs. eggs with polar caps), but also in the number of preanal papillae (4-6 vs. 7-10 on each side, respectively), and in the form of the distal tip of the larger (left) spicule (bifurcate, with narrow cuticular membrane vs. lanceolate, with wide cuticular membrane). From $R$. catostomi, $R$. paxmani and $R$. salmonis it differs in the character of eggs (irregular flock-like coating vs. one filament on each egg pole in $R$. catostomi and polar caps in $R$. paxmani and $R$. salmonis $)$ and in a shorter right spicule (0.082-0.102 vs. $0.151-0.154,0.115-0.135$ and $0.117-0.140 \mathrm{~mm}$ long, respectively).

Only two species of Rhabdochona have been reported from characid fishes: $R$. acuminata and $R$. uruyeni (both from South America) (Moravec 1998); however, the new species differs from them substantially in having fewer prostomal teeth (10 vs. 14).

Acknowledgements. The authors' thanks are due to the staff of the Laboratory of Electron Microscopy of the Institute of Parasitology, ASCR, in České Budějovice for their technical assistance and to Mrs. Irena Husáková of the Laboratory of Helminthology of the same Institute for her help with the preparation of illustrations. This study was supported by the Teaching Staff Improvement Programme (PROMEP) of the Autonomous University of Morelos State, Morelos, Mexico, by grant Nos. H007 and K028 from CONABIO, Mexico, by grant No. A6022901 from the Grant Agency of the Academy of Sciences of the Czech Republic and by grant No. K2-022601 from the same Academy. 


\section{REFERENCES}

ARAI H.P., MUDRY D.R. 1983: Protozoan and metazoan parasites of fishes from the headwaters of the Parsnip and McGregor rivers, British Columbia: a study of possible parasite transfaunations. Can. J. Fish. Aquat. Sci. 40: 1676-1684.

MORAVEC F. 1994: Parasitic Nematodes of Freshwater Fishes of Europe. Academia and Kluwer Acad. Publishers, Praha and Dordrecht, Boston, London, 473 pp.

MORAVEC F. 1998: Nematodes of Freshwater Fishes of the Neotropical Region. Academia, Praha, 464 pp.
MORAVEC F., COY OTERO A. 1987: Rhabdochona cubensis sp. n. (Nematoda: Rhabdochonidae) from the freshwater fish Gambusia punctata from Cuba. Helminthologia 24: 103-110.

SÁNCHEZ-ALVAREZ A., GARCÍA-PRIETO L., PÉREZPONCE de LEÓN G. 1998: A new species of Rhabdochona Railliet, 1916 (Nematoda: Rhabdochonidae) from endemic goodeids (Cyprinodontiformes) from two Mexican lakes. J. Parasitol. 84: 840-845. 